

\section{FICHA TÉCNICA}

\section{TÍTULO}

LIBRETOS

MATERIAIS PARA O FIM DO MUNDO - 8

Junho 2017

\section{PROPRIEDADE E EDIÇÃO}

INSTITUTO DE LITERATURA COMPARADA MARGARIDA LOSA

WWW.ILCML.COM |

VIA PANORÂMICA, S/N

4150-564 PORTO

PORTUGAL

E-MAIL: ilc@letras.up.pt

TEL: +351226077100

\section{CONSELHO DE REDACÇ̃̃O DE LIBRETOS}

\section{DIRECTORES}

ANA LUÍSA AMARAL

ANA PAULA COUTINHO

GONCCALO VILAS-BOAS

ROSA MARIA MARTELO

ORGANIZADOR DO LIBRETO № 11

PEDRO EIRAS

\section{AUTORES}

FÁTIMA OUTEIRINHO

JORGE COSTA LOPES

SOFIA ARAÚJO

\section{ASSISTENTE EDITORIAL}

LURDES GONÇALVES

\section{CAPA}

Instituto de Literatura Comparada Margarida Losa, a partir de uma fotografia de Renato Roque

PUBLICAÇÃO NÃO PERIÓDICA

\section{VERSÃO ELECTRÓNICA}

ISBN 978-989-20-7684-3

DOI: $10.21747 / 9789892076843 /$ fimdomundo8

OBS: Os textos seguem as normas ortográficas escolhidas pelos autores. 0 conteúdo dos ensaios é da responsabilidade exclusiva dos seus autores.

(C) INSTITUTO DE LITERATURA COMPARADA MARGARIDA LOSA, 2017

Esta publicação é desenvolvida e financiada por Fundos Nacionais através da FCT - Fundação para a Ciência e a Tecnologia, no âmbito do do Programa Estratégico "UID/ELT/00500/2013" e por Fundos FEDER através do Programa Operacional Fatores de Competitividade - COMPETE “POCI-01-0145-FEDER-007339".

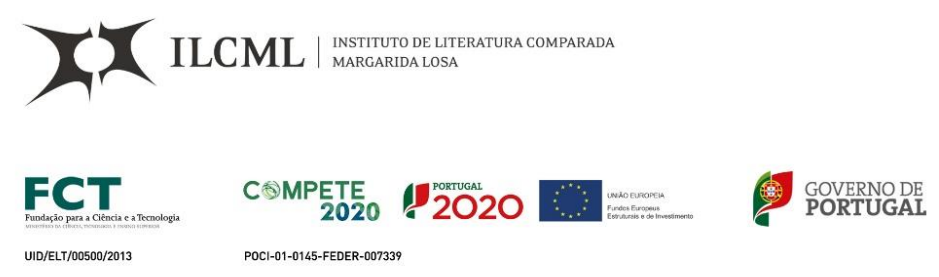


Libretos \#11

Materiais para o Fim do Mundo - 8

Org. Pedro Eiras

XX псми =

FCT

UID/ELT/00500/2013
CथMPETE $2020 \% 2020$

POC1-01-0145-FEDER-007339 



\section{Nota de abertura}

No dia 21 de Dezembro de 2012, a expectativa de um fim do mundo - tão espectacular quanto improvável - foi vivida à escala planetária. Entre terrores genuínos e um irónico ambiente de festa, a data fatídica passou sem incidentes, e profecias de novas datas para uma destruição do planeta começaram imediatamente a surgir.

O que é o fim do mundo? Um juízo universal da humanidade, conforme dizem os textos vetero- e neotestamentários? Uma catástrofe ecológica, global e iminente, provocada pelo homem? A alegoria de um mundo que perdeu as suas (meta)narrativas, vogando sem verdade e sem destino, após Auschwitz e Sarajevo? O pretexto para a sedução do espectáculo, entre filmes-catástrofe e um delicioso imaginário da destruição? Ou o confronto de cada qual com a sua morte própria? Por que nos fascina e aterroriza este tema milenar, nunca resolvido - e o que temos a ganhar com a exploração do nosso próprio terror?

Para estudar o imaginário do fim do mundo, o Instituto de Literatura Comparada Margarida Losa organiza, desde 2013, uma série de seminários abertos, coincidindo com os equinócios e os solstícios. Os libretos Materiais para o Fim do Mundo recolhem alguns ensaios apresentados nesses seminários, ou textos afins. Neste oitavo libreto, Maria de Fátima Outeirinho lê a obra de Léonora Miano, escritora nascida nos Camarões e vivendo em França, sob o ponto de vista do(s) fim(ns) do mundo africanos, marcado(s) pela história da escravatura e a questão das fronteiras, da memória, da pós-memória; Jorge Lopes revisita o universo de Vergílio Ferreira e o paradigma da aldeia destruída, paraíso perdido e ruína inelutável, à luz da "serenidade" heideggeriana e do "tom apocalíptico" analisado por Jacques Derrida; e Sofia Araújo avalia as inquietantes afinidades entre a not-so-short-story “The Machine stops", de E.M. Forster, e a nossa actualidade, dois universos fascinados pelo ideal da máquina perfeita e minados pela suspeita de uma morte da civilização.

Pedro Eiras 



\section{Fim do mundo - fim de mundo(s): um ângulo morto na memória africana?}

\section{Fátima Outeirinho}

Universidade do Porto - ILC

Resumo: Se o topos de uma humanidade e de um mundo ameaçados não é novo e é até frequente, na presente reflexão procura-se pensá-lo a partir de uma literatura estrangeira em espaço europeu, tendo como objeto um espaço africano e considerando vozes africanas, imersas num tempo colonial, mas com consequências num tempo pós-colonial, a envolver questões de construção de memória(s).

Palavras-chave: Léonora Miano, memória, imaginário de fim do mundo

Abstract: If the topos of a threatened humanity and world is not new and is even frequent, in the present reflection we try to think of it from a foreign literature in European space, having as object an African space and considering African voices, immersed in a colonial time, but with consequences in a postcolonial time, and involving memory building issues.

Keywords: Léonora Miano, memory, end of the world imaginary

Pensar o imaginário do fim do mundo pode passar por lembrar textos mais seminais como o Livro do Apocalipse, lembrar os discursos mais ou menos alarmistas dos nossos tempos anunciadores do fim do mundo, de fins de mundos e que a ficção integra como sucede com a ecoficção ${ }^{1}$, a ficção científica ${ }^{2}$ ou obras como Submissão (2015) de Michel Houellebecq, com narrativas mais ou menos distópicas, exercícios que também são de antecipação do futuro, para retomar uma expressão oitocentista. 
Numa primeira etapa de busca de um trilho, considerei tratar um corpus ligado à literatura de viagens, área de investigação que me interpela de modo particular. Falar de fim do mundo seria, neste contexto, lembrar desde logo a Patagónia, e presente nesta expressão está eminentemente uma delimitação física, geográfica, do observado. Decidi não ir por aí. Optei por não escolher narrativas de viagem. Não que os textos de viagem ou com viagens não possam também construir e/ou convocar representações do fim do mundo enquanto espaço-tempo para o medo, o desastre, a tentativa de decifração do inexplicável, mas igualmente a possível revelação da possibilidade e/ou necessidade de construção de novos mundos. Atentar em propostas criativas menos lembradas pareceu-me a via a seguir.

Porque não pensar outros caminhos do imaginário do fim do mundo, não tão palmilhados ou mesmo frequentemente ignorados em espaço europeu, mesmo se surgidos nesse mesmo espaço? Porque não acercar-me de caminhos percorridos com vista ao presente, mas que procuram desbravar um passado? Se o topos de uma humanidade e de um mundo ameaçados não é novo e é até frequente, pensá-lo a partir de uma literatura estrangeira em espaço europeu, tendo como objeto um espaço africano e considerando vozes africanas, pareceu-me a direção a seguir, contribuindo para a partilha de percursos de menor visibilidade no lugar em que me situo. Identificada a direção, a escolha do guia tornou-se, para mim, óbvia e a possível: Léonora Miano com A Estação da Sombra ${ }^{3}$ (Prix Femina, 2013). Porquê?

Sensivelmente desde 2008, tenho vindo a acompanhar a produção desta escritora de língua francesa, nascida nos Camarões (1973), mas a viver em França (desde 1991), com obra regularmente publicada desde 2005 - mais de uma dezena de títulos -; os seus textos dão conta de um projeto que se realiza pelo romance, por formas breves, pelo texto dramático ou pelo discurso ensaístico, mas ainda pela participação em iniciativas cidadãs. Muito embora a autora apresente textos vários situados em espaço europeu, francês, parisiense, em Portugal encontram-se traduzidos apenas três romances todos eles de contexto africano: O Interior da Noite ${ }^{4}$, Contornos do Dia que Nasce 5 e, o último, A Estação da Sombra.

Porém, ainda antes de me deter em A Estação da Sombra de Léonora Miano, importa talvez destacar dois aspetos: o primeiro prende-se com o que poderia ser 
denominado de processo de acantonamento da sua obra. Com efeito, a sua produção é com frequência alojada na chamada literatura de imigração ou numa literatura africana negra francófona e os próprios mecanismos de consagração literária ajudam a esse acantonamento. Tendo recebido inúmeras distinções ${ }^{6}$, é-lhe atribuído em 2010 por Les Aubes Écarlates o Trophée des Arts Afro-Caribéens (categoria romance) e, em 2011, recebe o Grand Prix Littéraire de l'Afrique Noire pelo conjunto da sua obra. Contudo, não podemos esquecer a difusão da sua obra através da tradução e, como lembra Pascale Casanova, "La traduction est la grande instance de consécration spécifique de l'univers littéraire" (1999: 188). Miano está presente num espaço plurinacional e já foi traduzida em português europeu e português do Brasil7, em inglês ${ }^{8}$, sueco ${ }^{9}$ ou italiano ${ }^{10}$. Como observa também Casanova em La République Mondiale des Lettres, "lorsqu'on cherchera à caractériser un écrivain, il faudra le situer deux fois : selon la position de l'espace national où il est situé dans l'univers littéraire mondial, et selon la position qu'il occupe dans ce même espace" (1999: 65) Caracterizar esta escritora é então reconhecer a existência de um acantonamento, como de resto sucede com tantos outros autores ligados ao universo da francofonia e que apresentam uma ligação a um antigo espaço de império colonial francês.

O segundo aspeto que desejo sublinhar tem a ver com a existência de um projeto estético delineado e explicitado pela própria autora ao longo do seu percurso e que as entrevistas e conferências que deu têm revelado. De resto, uma das suas obras - Habiter la Frontière (2012) - é precisamente uma recolha dessas mesmas conferências produzidas no Brasil, nos Estados-Unidos ou na Dinamarca, dando conta de todo um processo de reflexão metatextual que sustenta a sua escrita criativa. Situando-se na esteira conceptual de um Édouard Glissant, no que toca nomeadamente à questão da mondialité, a apontar para o contacto e encontro de culturas, no respeito pelo Diverso, e face à herança de um Ahmadou Kourouma no que concerne o dever de memória (Outeirinho 2014), Miano trabalha temáticas como o tráfico de escravos ou o discurso sobre a responsabilidade partilhada do destino da África contemporânea, num quadro que pretende fugir ao binarismo Europa-África e se quer antes situar num quadro transatlântico e em vivências partilhadas por toda a humanidade (Outeirinho 2011). Não por acaso, boa parte da sua obra aproveita uma herança literária e musical 
americana como lembra Sylvie Laurent quando afirma que essa herança "lui permet aussi de concevoir un imaginaire littéraire surprenant pour ses lecteurs: celui d'un 'tiers-espace', reliant par le fil invisible des mots et de leurs musiques, les territoires littéraires africains des trois continents" (Laurent 2011) A própria autora afirmará:

Par la force des choses, je suppose que j'appartiens à une génération d'écrivains africains, mais ce n'est pas en ces termes que je pense à moi. Je suis un écrivain, et si je travaille à partir de ce que je suis (africaine donc, à l'origine), il me semble surtout parler d'humanité dans mes romans. (Miano 2008: 5)

O projeto estético de Miano visa uma ação no presente, dando conta afinal do regresso do político ao facto literário (Viart, Vercier 2008) e a assunção de uma função social e ética da literatura. Eis alguns objetivos e chaves de leitura da poética de Léonora Miano ${ }^{11}$ que lembro para esta reflexão:

○ mostrar a pertença ou pelo menos a relação com um espaço literário mundial;

- assinalar uma poética de fronteira: “J'écris dans l'écho des cultures qui m'habitent: africaine, européenne, africaine américaine, caribéenne" (Miano 2012: 29);

○ salientar o hibridismo cultural de onde provém e de que dá testemunho;

- mostrar e demonstrar os traços partilhados por todos os grupos humanos e, portanto, uma pertença à humanidade;

- reconhecer a importância do tráfico negreiro, a travessia do Atlântico, para rastrear a memória e a responsabilidade africana neste processo e ir para além de particularismos redutores e parciais.

Sobre o papel de alguns africanos no tráfico negreiro dirá: "Pour seulement envisager de se projeter dans l'avenir, il est essentiel que cette histoire soit connue et appréhendée. Je ne pense pas que les sociétés africaines de ce début de XXIe siècle puissent faire l'impasse sur la connaissance précise de cette longue période." Neste contexto, em entrevista de 2013, Miano lembra que por exemplo nos Camarões não se fala dessa questão. A descoberta dá-se através do contacto com os afro-americanos que 
regressam para conhecer as suas raízes. Trata-se pois, como a própria autora refere, de combater "cet angle mort historique [qui] empêche d'envisager sereinement l'avenir" (Miano 2013). Nas suas obras de espaço africano, Miano não situa especificamente as narrativas no seu país de origem, mas numa África central banta: "Je crée dans mes livres un espace bantou imaginaire, ce qui me permet de sortir des divisions coloniales" (ibidem).

Será precisamente a questão do tráfico negreiro e as importantes transformações numa ordem vivencial africana que $A$ Estação da Sombra acolherá. Com base na investigação desenvolvida por Lucie-Mami Nor Nkaké, La Mémoire de la Capture, Miano erguerá um universo ameaçado e perturbador. Nos agradecimentos de final da obra, escreve a autora: "Muitos considerariam fastidioso um documento semelhante, com os seus aspetos por vezes técnicos. Todavia, eu descobri nele a confirmação de intuições muito antigas, que, tornadas obsessivas, irrigam a minha proposta literária" (Miano 2015: 235). Procurando dar corpo ao projeto estético a que aludi, trata-se em A Estação da Sombra da reivindicação de uma memória ${ }^{12}$, da tomada de responsabilidade africana no curso da História ${ }^{13}$ e tal passará por combater o silêncio e a vergonha que leva ao silêncio ${ }^{14}$; tal significa então mergulhar na estação da sombra ${ }^{15}$, num mundo ameaçado de desaparecimento, em perda de harmonia e de equilíbrio, com personagens confrontadas com a perda de referências, experimentando a impotência perante a destruição da aldeia, espaço vital de toda uma vida e de todo um povo, confrontadas com o exílio, face a um "mundo que cai aos bocados" (Miano 2015: 147).

Em A Estação da Sombra, o fim do mundo manifesta-se nas terras do clã mulongo, "Uma grande desgraça acaba de se abater sobre a aldeia" (idem: 12); o grande incêndio, "qualquer que tenha sido a sua causa, é um presságio sombrio, o anúncio dos tormentos que o clã sofrerá" (idem: 28), e o desaparecimento de dez jovens iniciados e dois homens de idade madura, a perda do ministro dos cultos, guia espiritual do povo, serão os sinais do caos que se instalará: "Desde o grande incêndio, apareceu uma nova categoria de indivíduos: a dos que não são vivos nem mortos. Ignora-se em que se tornaram" (Miano 2015: 24). A perplexidade, a incompreensão, a angústia e o medo atravessam o clã. Em $A$ Estação da Sombra, será o povo e o mundo dos Mulongo que irá ser destroçado pela 
traição do clã vizinho: os Bwele. Mukano, o chefe da aldeia em busca de uma resposta, não a encontrará:

Filho de Mulongo, disse o oráculo, nada voltará a ser como dantes. Eis que chegou o reinado de Mwititi [escuridão, sombra]. Esta fala não lhe dera as instruções que esperava. Incumbia-lhe a decisão, e ele tomou-a, a fim de honrar a sua condição. O Mal, ensinou-lho o seu pai, só existe para ser combatido. E acrescentava também, algumas vezes, as seguintes palavras que Mukano esquecera: Devemos lutar, sem estarmos certos de ver, nós próprios, o dia do triunfo. 0 chefe dos Mulongo solta um uivo que o trovão esmaga. Chove. (Miano 2015: 153)

0 reinado de Mwititi é a ausência de narrativas explicativas, tranquilizadoras, a impossibilidade de dizer um mundo que se estilhaça, um fim do mundo. Como considerará a matrona Ebeise, "A sombra é também a forma que os nossos silêncios podem tomar. (...) Sim, Mwititi é a forma que tomam os silêncios" (idem: 33). Contudo, o reinado da escuridão, da sombra, integra já a possibilidade da luz. E Mukano lembra a lição do pai: "Devemos lutar, sem estarmos certos de ver, nós próprios, o dia do triunfo" (idem: 153). Tal lição de um africano da África subsaariana faz-se de algum modo eco da epígrafe com que a obra abre, retirada de um texto que integra uma matriz judaicocristã do espaço europeu:

\footnotetext{
Sentinela, que vês na noite?

Sentinela, que vês na noite?

E a sentinela responde:

Vem aí a manhã e também a noite. (Isaías 21:11-12)
}

De um texto com ressonâncias apocalípticas como o é o Livro de Isaías, revela-se promessa de esperança num tempo a vir. Tais ressonâncias encontramo-las, de novo, no último capítulo da obra, intitulado "Últimos tempos", últimos dias, um capítulo só aparentemente de desesperança apesar da destruição, violência e morte que o atravessam. E também a segunda epígrafe do poeta haitiano Frankétienne aponta já na mesma direção, mesmo se sob uma forma interrogativa: “Oh que epopeia futura / reanimará as nossas sombras esvaídas?" (apud Miano 2015).

Um princípio de esperança, encontramo-lo em duas figuras femininas do clã pulverizado pelo exílio e dizimado pela morte. Em A Estação da Sombra, duas mulheres 
dão corpo e voz à necessidade de resistir e combater a sombra: Eyabe, mãe de um dos filhos que não tornaram a ser vistos, mulher viril que recusará a desistência perante um mundo que se desmorona, e partindo em busca do país da água para obter respostas, e Ebeise, a parteira do povo Mulongo, que fechará a narrativa, afirmando: "Saibamos acolher o dia quando ele se apresenta. E a noite também" (Miano 2015: 231). Acompanhada de uma criança, Bana, símbolo de todas crianças, uma criança que não é seu filho, mas que Eyabe faz seu, parte em direção à zona costeira e

Ao longo do caminho, continuou a ensinar-lhe o falar mulongo, nomeando, uma vez mais, os elementos presentes na natureza: madeira, folhas, terra. As partes do corpo. As acções: andar, comer, beber, dormir... O que lhe proporcionou um sentimento de apaziguamento. Partilhar, transmitir. Fazer de novo o mundo existir para um ser (idem: 156)

Face ao desaparecimento da sua comunidade e depois de sepultar os seus mortos, a matrona Ebeise parte e encontra Eyabe que lhe lembra a importância do dever de memória para construir o futuro, uma memória plural e partilhável16: "A mulher diz que vinte e sete pessoas foram enterradas no país de outrora. Os seus nomes serão transmitidos aqui, a fim de que os mortos saibam que um povo os reconhece e os reclama" (idem: 229). Assim, as bases para fazer uma nova comunidade estão lançadas.

A estação a que se reporta a obra é aquela em que os povos do interior africano começam a ser capturados por outros povos africanos seus vizinhos e vendidos aos homens com pés de galinha, denominação dada aos brancos que surgem do país da água:

Não têm realmente patas de ave, mas usam, por cima das pernas, roupas que dão essa impressão. Contara-me que os costeiros fazem há muito tempo comércio com esses estrangeiros que vêm de pongo pelo oceano. Outrora, pelo que pude compreender, forneciam-lhes óleo vermelho e presas de elefante. Desde então, fornecem-lhes gente, até mesmo crianças, em troca de mercadorias. (idem: 123)

Quer como vítimas, quer como carrascos, em A Estação da Sombra, os africanos serão os protagonistas num espaço onde os brancos parecem ser apenas figurantes. 
Ironicamente, o oceano que para o homem europeu, ocidental, representou a abertura e descoberta de novos mundos e que, antes da chegada do branco, representava em África o fim do mundo físico, terrestre ${ }^{17}$, após a chegada do branco, será o país da água que trará o fim do mundo para os povos africanos.

Para os que restam após a catástrofe que se abate sobre os seus mundos, resta a reunião de esforços, o reagrupamento e pôr em comum de heranças e memórias, a disponibilidade para um renascimento após dura travessia: "A mulher diz que esta terra se chama Bebayedi. É o país que se deram aqueles que escaparam à captura. Aqui, as recordações de uns misturam-se com as dos outros, para tecer uma história" (idem: 229).

Com esta obra, Léonora Miano procura de novo fazer a travessia das sombras interiores africanas. Como ela própria refere em Habiter la Frontière,

[Mes textes] sont un appel à la compréhension de soi-même, à l'acceptation de la responsabilité individuelle et collective comme premier levier pour se hisser vers une liberté pleine, entière. Ils sont également une exhortation au travail de mémoire qui tarde à se mettre en place sur le continent africain, à la recréation d'un lien avec les Afrodescendants, ce que je considère comme une des premières étapes vers la réhabilitation d'une conscience de soi actuellement assez dégradée en Afrique subsaharienne. (Miano 2012: 6)

"A sombra é também a forma que os nossos silêncios podem tomar", diz a mulher mulongo, Ebeise. Para preencher esses silêncios e construir novos mundos de futuro, Léonora Miano escreve $A$ Estação da Sombra, procurando anular o ângulo morto ${ }^{18}$ da memória africana, assente, afinal, num trabalho de pós-memória. ${ }^{19}$ 


\section{Bibliografia}

Casanova, Pascale (1999), La République Mondiale des Lettres, Paris, Éditions du Seuil.

Chelebourg, Christian (2012), Les Écofictions. Mythologies de la fin du monde, Bruxelles, Les Impressions Nouvelles.

Darriet-Féréol, Virginie (s/d), "La Saison de l'ombre de Léonora Miano, une enquête autour de la mémoire de la capture", http://phantasma.lett.ubbcluj.ro/?p=5902, consultado a 25-02-17.

Hirsch, Marianne (2008), “The generation of postmemory”, Poetics Today, 29:1, pp. 103128. http://eco-fiction.com/eco-fiction/, consultado a 25-02-17.

Laurent, Sylvie (2011), “Le 'tiers-espace' de Léonora Miano romancière afropéenne", Cahiers d'Études Africaines, http://etudesafricaines.revues.org/16857, consultado a 25-02-17.

“Léonora Miano : ce que l'esclavage a fait à l'Afrique” [propos recueillis par David Caviglioli, 27-10-2013] http://bibliobs.nouvelobs.com/romans/20131023.0BS2280/ leonora-miano-ce-que-l-esclavage-a-fait-a-l-afrique.html, consultado a 25-02-17.

Miano, Léonora (2005), L'Intérieur de la Nuit, Paris, Plon.

-- (2006), Contours du Jour qui Vient, Paris, Plon.

-- (2007), O Interior da Noite, trad. Joana Marques de Almeida, Lisboa, Europress.

-- (2008), Contornos do Dia que Nasce, trad. Joana Marques de Almeida, Lisboa, Europress.

-- (2008), [entretien conduit par Jérôme Destaing], in Afropean Soul et autres nouvelles, Paris, Flammarion.

-- (2008), Afropean Soul et autres nouvelles, Paris, Flammarion.

-- (2012), Habiter la Frontière, Paris, L’Arche.

-- (2013), La Saison de l'Ombre, Paris, Grasset.

-- (2015), A Estação da Sombra, trad. Miguel Serras Pereira, Lisboa, Antígona. 
Michel, Patrick (2002), “Ahmadou Kourouma, de l'Afrique à la 'totalité-monde'”, critique internationale, $\quad \mathrm{n}$ o 16 , www.cairn.info/zen.php?ID ARTICLE=CRII 0160070 , consultado a 25-02-17.

Outeirinho, Fátima (2011), “Quelle identité humaine? L’humain chez Léonora Miano”, in Krystyna Nodrzejeeska (dir.), La Condition Humaine dans la Littérature Française et Francophone, Opole, Uniwersytet Opolski: 95-101.

-- (2013), “Mouvances diasporiques chez Léonora Miano et Angeline Solange Bonono : le voyage extérieur et le voyage intérieur", in Ramona Malita et al., Agapes Francophones 2013, Szeged, Jate Press, pp. 169-178.

-- (2014), “L’héritage d'Ahmadou Kourouma dans la littérature contemporaine francophone: le cas de Léonora Miano", pp. 119-130, www.ilcml.com/Var/Uploads/ Publicacoes/Artigos/5486ddaf6e360.pdf, consultado a 25-02-17.

Socio-Anthropologie, no 28 (2013), https://socio-anthropologie.revues.org/1509, consultado a 25-02-17.

Stora, Benjamin (2012), Voyages en Postcolonies, Paris, Stock.

Viart, Dominique, \& Vercier, Bruno (2008), La Littérature Française au Présent, Paris, Bordas.

Fátima Outeirinho é Professora Auxiliar da Faculdade de Letras da Universidade do Porto, onde leciona nas áreas dos Estudos Franceses e da Literatura Comparada, tendose doutorado precisamente nesta última área de conhecimento. Integra o grupo Inter/transculturalidades no quadro do projeto Literatura e fronteiras do conhecimento: políticas de inclusão do Instituto de Literatura Comparada Margarida Losa. Desenvolve maioritariamente a sua docência e investigação nos domínios da Literatura Comparada, Literatura e Cultura Francesas (séculos XIX e XX), Relações Literárias e Culturais Portugal-França, Estudos sobre as Mulheres, Literatura de Viagens. É autora e organizadora de diversos estudos críticos nestes domínios. 


\section{NOTAS}

1 O conceito de ecoficção definido por Chelebourg identifica "les produits de ce nouveau régime de médiatisation des thèses environnementales. Leur champ ne se limite donc pas aux seules œuvres de fiction : il englobe l'ensemble des discours qui font appel à l'invention narrative pour diffuser un message écologique" (2012:11) Ver também http://eco-fiction.com/eco-fiction/: "Eco-fiction is ecologically oriented fiction, which may be nature-oriented (non-human oriented) or environment-oriented (human impacts on nature)".

${ }^{2}$ Não por acaso a investigação tem-se detido nestas ocorrências textuais como sucede, por exemplo, com o no 28 de 2013, da revista Socio-Anthropologie, sobre "Apocalypses".

3 Também por preocupação de partilha mais alargada de uma obra, de uma autora, optei pela tradução, em português, de Miguel Serras Pereira.

${ }^{4}$ O Interior da Noite, trad. Joana Marques de Almeida, Lisboa, Europress, 2007.

${ }^{5}$ Contornos do Dia que Nasce, trad. Joana Marques de Almeida, Lisboa, Europress, 2008.

${ }^{6}$ Em 2005 por L'Intérieur de la Nuit a distinção Révélation de la Forêt des Livres, Prix Louis Guilloux 2006, Prix René Fallet 2006, Prix Bernard Palissy 2006, Prix de l'Excellence Camerounaise 2007. Em 2006, por L'Intérieur de la Nuit o Prix Montalembert do primeiro romance feminino; ainda em 2006 o Goncourt des Lycéens, por Contours du Jour qui Vient; o Prix Grinzane Cavour em 2008 (categoria primeiro romance estrangeiro); em 2010 por Les Aubes Écarlates o Trophée des Arts Afro-Caribéens (categoria romance); por Soulfood Équatoriale o Prix Eugénie Brazier em 2009; e em 2012 Écrits pour la Parole foi distinguido com o Prix Seligmann contra o racismo.

${ }^{7}$ Contornos do Dia que Vem Vindo (2009). A tradução inscreve-se no contexto da comemoração do ano da França no Brasil, em 2009.

${ }^{8}$ Dark Heart of the Night (2010).

${ }^{9}$ Konturer av den dag som nalkas (2008).

${ }^{10}$ Notte Dentro, 2007 e I Contorni dell'Alba (2008).

${ }^{11}$ Cf. Sigo de perto a síntese já apresentada em "L'héritage d'Ahmadou Kourouma dans la littérature contemporaine francophone: le cas de Léonora Miano", www.ilcml.com/Var/Uploads/Publicacoes/Artigos/5486ddaf6e360.pdf.

${ }^{12}$ Cf. Miano (2006: 211 e 2009: 157, 210).

${ }^{13}$ Cf. Miano (2005: 213).

14 "La honte est pour beaucoup dans ce silence. Il y a une autre honte: celle d'avoir été colonisé par d'anciens partenaires commerciaux" (Miano 2013). 
15 “Le défi est de faire en sorte que les heures sombres du passé deviennent enfin l'Histoire, pas un présent perpétuel" (Miano 2010: 49).

16 Como para Benjamin Stora, trata-se de defender "une mémoire chorale, plurielle, partageable" (Stora 2012: 134).

17 "este país pertence realmente a Wase. Mas a terra detém-se aqui. Para lá desta terra, não há senão água. Se o lugar que procuras é a borda do nosso mundo, chegaste ao teu destino" (idem: 162-163).

18 Cf. "cet angle mort historique empêche d'envisager sereinement l'avenir." http://bibliobs.nouvelobs.com/romans/20131023.0BS2280/leonora-miano-ce-que-l-esclavage-a-fait-a-lafrique.html

${ }^{19}$ Na verdade, como também lembra Marianne Hirsch, "Postmemory's connection to the past is thus not actually mediated by recall but by imaginative investment, projection, and creation" (2007: 107). 


\title{
O homem é cada vez mais improvável? o fim do mundo segundo Vergílio Ferreira
}

\author{
Jorge Costa Lopes \\ Universidade do Porto - ILC
}

Resumo: 0 nosso ensaio pretende elaborar uma reflexão sobre o fim do mundo na obra literária de Vergílio Ferreira. Privilegiamos, para o efeito, um tríptico romanesco em que são mais evidentes as cores apocalípticas nos seus quadros narrativos: Alegria Breve, Nítido Nulo e Signo Sinal. Nestes romances o arquiprotagonista vergiliano vive um tempo de crise sem fim à vista, contrapondo porém a esse cenário escatológico a serenidade heideggeriana. Mas, perdida a esperança de o filho fundar uma nova cidade, o homem é cada vez mais improvável, pelo que é chegado o momento de o arquiprotagonista criar, no chamado "último Vergílio", a sua Solaris privativa, isto é, a solarística ou ciência da palavra que lhe dá acesso ao seu planeta imaginário. Através dessa ciência recupera o seu amor maior do que a vida, ou seja, a mulher morta no presente da escrita.

Palavras-chave: Vergílio Ferreira, Alegria Breve, Nítido Nulo, Signo Sinal, fim do mundo, serenidade

Abstract: Our essay aims to elaborate a reflection upon the end of the world as a matter in Vergílio Ferreira's literary work. For this purpose, we highlight a triptych of novels in which the apocalyptic colors are more evident in their narrative frames: Alegria Breve, Nítido Nulo and Signo Sinal. In these novels, the vergilian archiprotagonist lives a time of crisis with no end, contrasting, however, this eschatological scenario with the Heideggerian serenity. But loses the hope of his son to ground a new city, humankind becomes more and more unlikely, so now comes the time for the archiprotagonist to create, in the socalled "last Vergílio", his private Solaris, i.e, the solaristic or science of the word that gives him access to his imagined planet. Through this science regain his greater than life love, that is, the deceased woman in the present of the writing.

Keywords: Vergílio Ferreira, Alegria Breve, Nítido Nulo, Signo Sinal, end of the world, serenity 
A esta hora do Fim a única música audível é um dobre de finados. Ressoa no esplendor das artes, nos gabinetes dos estudiosos da História, da filosofia, nos templos desertos excepto para o turismo mesmo religioso e no mais. Mas vê se consegues dar conta de uma flor aberta, da luz, de um pássaro irresponsável a cantar. E sorri.

(Ferreira 2001: 120)

Começamos pelas mais recentes notícias sobre o fim do mundo: "Milionários estão a gastar fortunas com medo do fim do mundo"1 e "Como os milionários se preparam para o fim do mundo"2. Ora, no filme 2012 de Roland Emmerich ${ }^{3}$ uma tribo similar do nosso esplendor do caos (Eduardo Lourenço) supõe ter ouro suficiente para adquirir o selo divino e marcar o grupo restrito de eleitos que supostamente sobreviverão ao Apocalipse. São reflexões como esta de Jean Baudrillard que provocam, aliás, a angústia aos nossos candidatos a Rei Midas: "a morte é talvez a única coisa sem valor de uso, nunca remete para a necessidade, o que a pode transformar numa arma absoluta" (1997: 90).

Daqui passamos para uma entrada do diário de Vergílio Ferreira, datada de 16 de agosto de 1984, que regista outras notícias, igualmente alarmantes, mas, convenhamos, menos surpreendentes:

Como pensar ainda em cultura, arte, figurações da vida humana num tempo que é só de morte? Como abrir o espaço do nosso repouso espiritual, dos projectos e realizações de uma comunidade de homens vivos, quando o espaço que se lhes abre é o de um campo de cadáveres? Em certos instantes ilumina-me a evidência de que somos palhaços de nós próprios, bobos para o riso do destino, seres infantis na inconsciência que nos ameaça. Um fim do mundo acelera-se não na disposição das forças cósmicas mas das da loucura humana. Os noticiários de cada hora só têm para nos entreter o gosto do terrível e do macabro, os desastres de guerra que alastra por toda a parte. 
Nós estamos dependentes de um breve gesto de distracção, do capricho ou da loucura que nos reconduzam a Terra à sua condição primitiva de planeta deserto. Nós jogamos xadrez, como no poema de Pessoa, enquanto à volta a destruição se aperta sobre nós ${ }^{4}$. A cultura é uma aposta no homem e no futuro. Nós não temos futuro e o homem é cada vez mais improvável. (Ferreira 1986a: 314, itál. nosso)

Consideremos, desde logo, que as páginas desta Conta-Corrente e dos livros de reflexões, Pensar e Escrever, trazem uma evidente marca daquilo a que podemos chamar o sentimento trágico e escatológico do autor; o mesmo é dizer que são recorrentes os fragmentos sobre a crise da condição humana e o fim de uma civilização ou de um mundo, como lemos igualmente neste excerto:

Mundo da desagregação, da arte em farrapos, da política em ruínas, da religião sem fé como lareira sem fogo, da moral incompreensível e amoralidade normalizada, do fútil e efémero, do presente rápido sem futuro nem passado, dos filhos sem pais que não tiveram tempo para isso, do lixo, do estrume, da grande manta de caca a envolver e preencher tudo quanto foi um dia o lugar de se ser homem em arte, em cultura, em tudo o que foi razão de o ser. (Ferreira 1993b: 166)

$\mathrm{Na}$ realidade, temos por vezes a impressão de que para Vergílio Ferreira a destruição dos valores milenares do homem, provocada pela crise da religião, da arte, da política e das relações sociais, coloca-nos muito próximos do fim de um mundo ou do fim do homem como o conhecemos desde, pelo menos, a Grécia Antiga. O carpe diem horaciano parece, assim, integrar uma das atitudes possíveis face aos ventos de destruição que sopram no presente:

É a palavra de ordem para o homem de hoje. Destruir. Tudo. Os deuses, as artes, diferenças culturais, ou a só cultura, diferenças sexuais, diferenças literárias ou a só literatura que leva hoje tudo, valores de qualquer espécie, filosofias, o simples pensamento, a simples palavra - tudo alegremente ao caixote. (...) É tempo de cair um pedregulho como o que acabou com os dinossauros há sessenta milhões de anos e de poder dar-se a hipótese de a vida recomeçar. Até que venha outra vez a destruição e Deus definitivamente se farte do brinquedo. Entretanto vê se vês ainda alguma flor ao natural e demora-te um pouco a admirar-lhe a beleza e estupidez. (Ferreira 2001: 152-153) 
Estas e outras reflexões aproximam-se desta longa e escatológica lista de Jacques Derrida:

o fim da história, o fim da luta de classes, o fim da filosofia, a morte de Deus, o fim das religiões, o fim do cristianismo e da moral (isto, esta foi a ingenuidade maior), o fim do sujeito, o fim do homem, o fim do Ocidente, o fim de Édipo, o fim da Terra, Apocalypse now, eu digo-vos, no cataclismo, no fogo, no sangue o sismo fundamental, o napalm que cai do céu por helicópteros, como as prostitutas, e também o fim da literatura, a arte como coisa do passado, o fim da psicanálise, o fim da universidade (1997: 43) ${ }^{5}$

Para Jean Baudrillard o fim do mundo já aconteceu, porque tudo, afinal, se passou e nós já não estamos neste mundo, mas num outro, onde o "advento do próprio virtual é o nosso apocalipse e priva-nos do acontecimento real do apocalipse" (1998: 35), o mesmo será dizer que o apocalipse está em todo o lado e em lado nenhum, ou, ainda nas suas palavras,

Acabou-se a subversão política, acabou-se a 'libertação' do desejo ou do inconsciente, nem tãopouco existe já a hipóstase do significante nem sequer o leitmotiv utópico da alienação provida de uma subjetividade radical. Fim da metalinguagem, fim da metafísica, fim da metáfora em proveito do signo puro, do acontecimento puro. Porque tudo está realizado, já nada está no fim, tudo está já lá: ou seja, para além do fim. (idem: 139)

Heidegger, pelo seu lado, apontou para a possibilidade deste apocalipse em Introdução à Metafísica, ao diagnosticar o "declínio espiritual da terra" (1997: 46) e, sobretudo, "o obscurecimento do mundo, a fuga dos deuses, a destruição da terra, a massificação do homem, a suspeita odienta contra tudo o que é criador e livre" (ibidem), acrescentando, mais à frente, a "primazia do medíocre" (idem: 52), antes de colocar a seguinte questão: "Que significa mundo, quando falamos de um obscurecimento do mundo?" (ibidem) ${ }^{6}$.

Nas imediações da reflexão de Baudrillard, Eduardo Lourenço considera que somos já sobreviventes do fim do mundo inaugurado em Hiroshima. Para o ensaísta português, este "tempo de Hiroshima", como lhe chama, é o "do big bang às avessas, não o de um começo infinitamente aberto, mas de um fim apenas humanamente diferido" (2002: 99). Os Estados Unidos da América abriram, naquele dia 6 de agosto de 1945, as 
portas de um outro tempo ou tempo novo, o do apocalipse real e impensável, fora da história. Por isso ao passar meio século do lançamento da bomba atómica, os americanos "não puderam comemorar-se como actores do mais sinistro e irreversível western da sua história" (idem: 101). Os japoneses, povo de samurais outrora invencíveis, logo sentiram necessidade de esquecer e reconstruir a cidade. Eduardo Lourenço considera, contudo, que deveriam "tê-la conservado assim, arrasada, como Cartago pelos novos romanos, insuportável à vista e intolerável para o coração" (idem: 102). Não concordamos com o autor de $O$ Esplendor do Caos, pois os japoneses evitaram, afinal, algo mais insuportável do que contemplar as ruínas da cidade arrasada: as hordas de turistas que inevitavelmente fariam hoje de Hiroshima uma atração festiva. Ainda de acordo com a perspetiva escatológica lourenciana, não "admira que nesta atmosfera de 'fim do mundo' ou promessa de outro em relação ao qual nós temos já a consciência de ser meros 'mutantes' um pouco por toda a parte renasça uma religiosidade ou uma misticidade futurante que parecia sem futuro" (Lourenço 2001: 40-41).

Apesar de o homem ser cada vez mais improvável (Vergílio Ferreira), apesar do apocalypse now (Derrida), de estarmos para lá do fim (Baudrillard), em pleno "declínio espiritual da terra" (Heidegger) ou de sermos meros mutantes que vivem numa atmosfera de fim do mundo (Eduardo Lourenço), descobrimos a esperança nestes versos do poema "Patmos" de Hölderlin: “onde está o perigo, cresce / Também o que nos salva" (Hölderlin 1991: 407). Mesmo que seja coisa "terrível de ver como pra aqui e pra além / Infinitamente dispersa Deus o que vive." (idem: 415).

Ora de acordo com Alexandre Franco de Sá, que cita estes versos de Hölderlin,

O pensar de Heidegger em torno da essência da técnica moderna consiste não num pensar do fim do mundo, mas num pensar de um 'outro início'. (...) Ao deter-se diante do fim, tornando-se assim meditação, o pensar de Heidegger é essencialmente marcado pela abertura a um 'vindouro', a um Zu-künftiges, que surge, diante da história do abandono do ser que constitui a história do primeiro início deste mesmo ser, como um 'outro' início. (2007: 250-251) 
Regressando ao apocalipse derridiano, Luís Mourão anota que o "pensamento actual está possuído pela obsessão do fim" (1990: 93), pelo que Vergílio Ferreira não se podia abstrair desta "problemática do fim" (ibidem), ainda que sob uma ótica "algo sinuosa" (ibidem). 0 ensaísta refere-se especificamente à oscilação do autor de Signo Sinal entre um tom apocalíptico e "a serenidade de quem vê que está tudo ainda por fazer" (ibidem). Estamos plenamente de acordo com esta análise que nos dá, segundo entendemos, uma das chaves da reflexão vergiliana sobre a destruição do mundo. Na realidade, o ponto de vista do autor de Aparição em relação à crise civilizacional e ao consequente pessimismo sobre o futuro do homem contém uma evidente conexão com a serenidade, tal como o Apocalipse de S. João se inscreve numa dicotomia que inclui o bem e o mal, o justo e o réprobo, a salvação e a condenação, a violência e a tranquilidade, o céu e o inferno, Deus e o Diabo.

A dicotomia vergiliana ${ }^{7}$ estabelece, deste modo, um diálogo com o apocalipse bíblico e as reflexões de Heidegger assinaladas na conferência que deu origem ao ensaio intitulado Serenidade, onde se confrontam o pensamento que calcula e o pensamento que medita, o primeiro associado ao "mundo técnico" (Heidegger 2000: 23) e o segundo ao tranquilo habitar entre a terra e o céu. Para o filósofo alemão, ainda não "reflectimos que se prepare aqui, com os meios tecnológicos, uma agressão à vida e à natureza humana, comparada com a qual a bomba de hidrogénio pouco significa" (idem: 21). Deste modo, o que o inquieta não é a técnica invadir o mundo do homem, mas o homem "não estar preparado para esta transformação do mundo" (ibidem). 0 mesmo sucederá, acrescentamos nós, na "aldeia eterna" do arquiprotagonista vergiliano de Alegria Breve e Signo Sinal. A serenidade não abdica do mistério e do enraizamento para se encontrar com a essência do homem. Dessa maneira, a reflexão alcança a serenidade e impede que o homem renegue o que "tem de mais próprio, ou seja, o facto de ser um ser que reflecte" (idem: 26).

Ora o fim do mundo ou "mundo do fim" (Cunha 2000: 80) vergiliano surge, desde logo, embora em moldes embrionários, no romance de estreia, O Caminho Fica Longe, mais concretamente num poema do seu protagonista e alter ego do autor, Rui Antunes, 
onde são visíveis, nos últimos versos, os quadros escatológicos dos romances futuros de Vergílio Ferreira:

\author{
Se ao menos viesse a noite \\ com seu manto de bondade \\ e ocultasse a estrada negra \\ por onde correm os homens \\ naquela esperança inútil \\ da Fonte Miraculosa \\ e Encoberta...
}

Mas não.

Quando a noite descer,

de todos esses mundos restarão apenas

montões de carne podre

que fedem... (Ferreira 1943: 201)

Na última noite que Alberto Soares, narrador-protagonista de Aparição, dorme na casa do Alto, em Évora, observa uma "queimada" numa "vasta extensão de terreno" (Ferreira 2004: 268) e relaciona-a com a destruição da sua cidade do Homem que não resistiu, afirmamos nós, às trágicas mortes do Bailote, da pequena Cristina e, sobretudo, de Sofia, assassinada por Carolino, aluno do narrador. 0 incêndio e a aparição a negro de Carolino - que representa, de algum modo, o papel do anjo caído - testemunham, desta maneira, o malogro da revelação existencial que Alberto Soares pretendia trazer à cidade cercada de muralhas. Há, então, que recomeçar tudo de novo e erguer a sua Jerusalém sem Deus nem deuses noutro local. Enquanto no romance Nítido Nulo, Jorge Andrade assistiu a um filme intitulado A Cidade Morta - que parece apontar, desde logo, para o malogro da esperança de Alberto Soares, aqui transmudada em "esperança inútil"8 -, do qual apenas se recorda, no presente da escrita, da música de fundo. É uma música com o mesmo título do filme que divide a plateia e o mundo em réprobos e eleitos. A trompete desta música anuncia ainda a trombeta do Apocalipse de S. João:

Era de um compositor americano - Fokland? Suponhamos. Havia uma orquestra e uma trompete cortava-a de alto a baixo, cortava a plateia, dividia o mundo. E separava decerto para um lado os réprobos e para o outro os eleitos (...) Dentro em breve serei o nada de antes de nascer. Entre um 
nada e outro estará a memória do que sou e será nada também. (...) A morte só é terrível quando a vemos da vida, quando entre nós e o seu nada há um tudo a perder. (...) A paixão é a vida. E decerto por isso, ao anúncio de uma trombeta final, toque a silêncio, coalhado de angústia ouço-o na solidão da noite (...). E foi só o que me restou do filme, para a cidade morta, música do fim. (Ferreira 1989: 57-58)

Maria Joaquina Nobre Júlio destaca neste episódio o fantástico associado ao teratológico e ao monstruoso (1996: 94-95). Para a mesma ensaísta, a cidade-símbolo de Nítido Nulo é palco, em conjunto com a aldeia de Alegria Breve e de Signo Sinal, da "destruição universal” (idem: 95). Estamos, então, no terreno intertextual do Apocalipse de S. João, onde lemos que, a seguir à prisão do Dragão (isto é, de Satanás), foram

abertos livros; depois foi aberto um outro livro: o da Vida; os mortos foram, então, julgados segundo o que foi escrito nos livros, cada um segundo as suas obras. 0 mar restituiu os mortos que havia nele9; a Morte e o Inferno entregaram os mortos que guardavam e cada um foi julgado segundo as suas obras. (...) E quem não estava inscrito no livro da Vida, foi precipitado no lago de fogo. (Ap 20:12-13 e 20:15)

A cidade morta de Nítido Nulo - não a do filme, mas a que Jorge Andrade percorre na companhia dos sete músicos que abandonam o ecrã de cinema, como sucederá com o arqueólogo, interpretado por Jeff Daniels, em A Rosa Púrpura do Cairo de Woody Allen (1985) - tem uma tinta similar à do indicado quadro bíblico, embora o narrador discorde, por vezes com uma nota irónica, do livro da Vida e do juízo final nele incluído:

\footnotetext{
E a todo o espaço de luzes, cidade morta, como círios as luzes, cadáver abandonado à noite, um milhão de cadáveres. Insepultos, o cheiro cresce podre ${ }^{10}$, um vómito na garganta. Como no fim de uma batalha, que batalha? Porque a guerra continua. Amontoados na podridão comum, à trombeta do juízo final separar-se-ão na fronteira da justiça, mas não sei bem de que justiça. Porque cada juízo final é um juízo provisório diante do outro juízo final que há-de ser provisório. E os mortos não podem nunca defender-se, mesmo que necessitados. Perderam a capacidade de invenção, só sabem repetir-se. (Ferreira 1989: 60)
}

Além da trompete que atravessa, em Leitmotiv, a narrativa de Nítido Nulo e que sobressai, como assinalámos, na banda sonora do filme A Cidade Morta, relevamos também os quatro pregadores que irrompem, cada um deles, em diferentes fases da vida 
de Jorge Andrade. 0 discurso deste quarteto parodia, quase sempre, o texto bíblico, embora professando uma espécie de evangelho às avessas. Assim, o pregador que se encontra com o narrador-protagonista, no tempo da Faculdade, diz-nos que é chegada a hora do Não ${ }^{11}$, pelo que, se alguém disser que fornicar é pecado, a resposta deve ser não, porque "dos fornicadores é o reino dos céus" (Ferreira 1989: 78). E prossegue: "Queimai os livros todos, porque a verdade ainda não foi escrita e dos novos ignorantes é o reino dos céus" (idem: 79). Ele traz, efetivamente, uma outra verdade à terra dos homens e assegura que pecar é não desobedecer à Grande Lei, apesar de se socorrer ironicamente de uma matriz lexical semelhante à da Lei que recusa, ao inverter-lhe os seus dogmas: “- Em verdade vos digo que a cólera da justiça vai abrasar toda a terra. E a terra será pura outra vez e o homem poderá então construir a sua morada" (ibidem).

Sobre a destruição do mundo no imaginário vergiliano, escreve Maria Joaquina Nobre Júlio:

A dissolução e a morte do mundo não se dão, nos romances de Vergílio Ferreira, repentinamente. Elas vêm sendo preparadas, anunciadas progressivamente, de narrativa para narrativa, até a morte surgir, como fenómeno cósmico, em Alegria Breve e Signo Sinal, no simbolismo universal das duas aldeias destruídas (1996: 92)

Na realidade, para o autor de Para Sempre estão "em crise todas as religiões, todos os sistemas políticos e morais, todas as aventuras da Arte" (Ferreira 1991: 288), mas, acrescentamos nós, enquanto o sonho do homem e "a sua continuidade na aventura da vida" (ibidem) conduzirem a esperança no caminho de um mundo novo, como sobressai nos romances citados por Maria Joaquina Nobre Júlio, o homem sobrevive à morte de Deus, mantendo a sua probabilidade e contrariando o exposto no fragmento de Conta-Corrente transcrito no início do nosso ensaio. De qualquer modo, como veremos, a serena melancolia do arquiprotagonista do "último Vergílio" perdeu pelo caminho a esperança de Alberto Soares e Jaime Faria na possibilidade de um homem novo.

Para A. Vaz da Mota, "fim do mundo, escatologia, novíssimos, vem tudo a significar o mesmo, ou seja, o fecho da história humana, o juízo final, a ressurreição dos mortos, o retorno de Cristo (parusia)" (AA.VV. 1984: 1057). Em Alegria Breve a parusia é substituída, assim, pela esperança na vinda no filho de Jaime Faria: 
De qualquer forma, as revelações referentes à escatologia nunca poderão tomar-se como reportagens antecipadas de coisas que terão de acontecer mais tarde. São, antes, uma resposta ao olhar inquiridor que o homem, do momento histórico que está vivendo da salvação trazida por Cristo, lança ao desenlace definitivo da sua situação existencial, a fim de aí encontrar razões e ânimo para aceitar o presente como um futuro já secretamente actual (idem: 1058)

Quando iniciamos a leitura de Alegria Breve, "Águeda, a mulher do narradorpersonagem, está já morta e o mundo despovoado, como se o apocalipse se tivesse cumprido. A eterna aldeia de Vergílio Ferreira é uma aldeia não só exteriormente morta, mas espiritualmente morta", escreve Eduardo Lourenço (1994: 126). No mesmo incipit o narrador-protagonista anuncia o seu programa existencial: “Do desastre universal, ergome enorme e tremendo" (Ferreira 1986b: 15). A alegria breve, como salienta o autor num documento preparatório deste romance, diz respeito à "esperança para o futuro" 12 , ou seja, na esperança da vinda do filho que Jaime Faria supostamente teve com Vanda, após falhar o projeto de Águeda de lhe dar um herdeiro. Porque, morto Deus - o telhado da igreja ruiu após o Padre Marques deixar a aldeia -, o homem terá de construir a sua morada, pelo que Jaime é "o Alfa e o Ómega, o Princípio e o Fim" (Ap 21: 6). E o seu filho terá necessariamente de vir um dia para criar "um céu novo e uma terra nova" (Ap 21: 1 Is. 65,17$)$ :

Idos, mortos, desaparecidos - fiquei eu, alguém tinha de ficar. Um dia a terra será de novo habitada, um dia a vida será outra vez. Meu filho voltará - quem poderá voltar se ele não? espero-o sempre. Dir-lhe-ei a palavra nova que me queima a boca, ele transmiti-la-á aos que vierem depois:

- Esquece tudo. Foi tudo um erro. Recomeça.

(...) 0 mundo tinha de morrer, e é só. Havia muita coisa a iludir-te. Um dia cairia a neve sobre a aldeia abandonada, e viria o sol para a dizer intacta e nula até ao mais remoto limite (Ferreira 1986b: 99 $)^{13}$

Mas no romance Até ao Fim é Flora - mãe sempre ausente do malogrado filho do narrador-protagonista e sem qualquer afeto maternal - que curiosamente anuncia: "Nós 
temos de voltar ao princípio, Cláudio, nós temos de voltar a nascer. E a Grécia é o lugar próprio para isso" (Ferreira 1988: 130).

Segundo Roland Barthes, Lacan destacou o facto de "os verdadeiros ateus [serem] muito raros. Há sempre sagrado algures" (Lacan apud Barthes 1982: 271). Aforismo que se aproxima deste outro de $O$ Mito de Sísifo de Albert Camus: "Até os homens sem evangelho têm o seu Monte das Oliveiras" (1949: 131)14. Ora, apesar do ateísmo inicial do arquiprotagonista vergiliano, substituído mais tarde pelo agnosticismo, o léxico bíblico e o sagrado imiscuem-se neste discurso de Jaime Faria, como se imiscuem em toda a ficção vergiliana. A Bíblia constitui, deste modo e em nossa opinião, um dos hipotextos principais, senão mesmo o principal, da ficção de Vergílio Ferreira:

clamo a morte do homem, anuncio a sua vinda - Natal. Choro meu de alegria, ó anjos da nova pura. Cântico dos anjos da anunciação, dos anjos das trevas e do desastre, os sinos bradam para o vazio do mundo. Virgindade do meu sangue, um Deus Menino vai nascer. Os deuses nascem sobre o sepulcro dos deuses. (Ferreira 1986b: 207)

Luís Barreto e o padre Marques são dois dos interlocutores privilegiados do narrador-protagonista de Alegria Breve. 0 primeiro esteve, no passado, na origem da tecnificação da aldeia como responsável pela exploração do volfrâmio. A desertificação atual é, aliás, o resultado do abandono das minas de volfrâmio. Mas onde o conflito de Jaime com Luís Barreto pode agudizar-se é na questão do filho de Vanda - mulher de Luís Barreto e amante de Jaime Faria. Assim, repovoar a aldeia e criar um mundo novo é a tarefa que este destina para o seu suposto filho biológico, enquanto para o engenheiro de minas o filho de sua mulher será o herdeiro e continuador do seu império económico. Porque, apesar de estéril, Luís Barreto possui, ironicamente, o dom de fazer nascer "dinheiro das pedras" (Ferreira 1986b: 119) com o seu toque, como o Rei Midas e certamente os milionários do século XXI da notícia atrás referida. Como vemos, estabelece-se aqui um confronto entre o intelectual (Jaime Faria) e o homem técnico (Luís Barreto), pelo que a escolha futura do filho de Vanda de ficar com o suposto pai biológico ou com Luís Barreto parece apontar para a escolha futura do próprio homem entre o pensamento e o conhecimento técnico-científico ou, na dicotomia heideggeriana 
atrás mencionada, entre o pensamento que medita ou reflete e o pensamento que calcula.

O filho do narrador-protagonista de Até ao Fim possui, porém, outros planos e metamorfoseia-se numa espécie de Heróstrato ${ }^{15}$, como afirma no último diálogo tido com o pai:

Miguel disse: estamos fartos de palavreado, a acção directa

- Em nome de quê?

- Criar o remorso.

- Porque tu crias o motivo a partir do que fazes.

- Queimar a terra para semear.

$[\cdots]$

- Uma náusea de tudo isto - disse ele - Só o preço é que dá o valor, não o contrário. (Ferreira 1988: 240-241)

Já chamamos a atenção para o diálogo de Alegria Breve e Nítido Nulo com o Apocalipse de São João. A que juntamos agora o romance Signo Sinal que inclui o registo de um "mosaico de citações da Escritura, em que predomina o tom apocalíptico", como sinalizou Maria Joaquina Nobre Júlio (1996: 105) em relação ao discurso das três mulheres do capítulo XVII deste romance. A penetração do texto bíblico, neste episódio, traz ainda a marca da circularidade, pois a prédica deste alucinado trio feminino começa e acaba na imagem da eliminação do homem, retirada de Génese, 6:7: "E disse o Senhor: destruirei de sobre a face da Terra o homem que criei” (Ferreira 1979: 111 e 113).

"Que imagem de fim, de desolação e ruína? não da aldeia, de outra coisa imensa, pelo espaço de um universo vazio" (idem: 61) - interroga-se o narrador de Signo Sinal. Uma resposta possível a esta questão traz, afinal, a marca de um (im)possível tempo do fim do mundo:

Dentro de duzentos anos todos os biliões de seres humanos que há sobre a Terra estarão mortos. Dentro de alguns biliões acabarão os seres vivos. O Sol há-de apagar-se, as trevas envolverão o mundo para sempre. Um dia, no futuro, todo o Universo será morto. Mas este desafio lançado à morte. Uma aldeia arrasada, uma aldeia reconstruída, os deuses estremecem nos seus túmulos. (idem: 61) 
Daniel, narrador-protagonista de $\mathrm{Na}$ tua Face, oferece uma outra versão do brevíssimo milagre da vida, antes do desaparecimento do homem e da própria Terra, sem qualquer parusia ou ressurreição possível:

Depois de biliões e biliões de milénios há um segundo em que apareceu a vida. E nesse segundo um instante mais rápido que o flash da Luz em que houve vida animal. Num milionésimo desse instante houve homens. E a certa altura tudo se apagou de novo e houve biliões e biliões de silêncio e de treva (...) depois há o silêncio sem fim de um astro morto que é a Terra. É assim. Que é que isto pode querer dizer? Um simples episódio que aconteceu passou acabou. (Ferreira 1995: 131)

A serenidade faz parte, todavia, da condição do narrador-protagonista de Signo Sinal no presente da escrita. 0 sismo que praticamente arrasou a aldeia não impede Luís Cunha de usufruir do encantamento e da pacificação de uma tarde quente de verão numa praia do Sul. E de manter a esperança no homem novo, desafiando os deuses mortos. Com a partida dos construtores do futuro, as obras ficam suspensas, assemelhando-se a aldeia, na sua incompletude, a "uma civilização perdida" (Ferreira 1979: 240). Mas Luís Cunha recupera, no explicit, a esperança na perfeição e no futuro: "Vou sair da aldeia, vou visitar a alegria. (...). Visitar a esperança. A perfeição" (idem: 241-242).

Nos romances indicados de Vergílio Ferreira encontramos ainda, além do texto bíblico, uma outra matriz intertextual: a que se relaciona com o mito de "Er, o Arménio, Panfílio de nascimento", da República de Platão. Efetivamente, a viagem de Panfílio pelo reino dos mortos, na qualidade de "mensageiro, junto dos homens, das coisas do além" (Platão 2008: 485), foi referida, por Vergílio Ferreira, como integrando um "belo mito" (Ferreira 1993a: 212), sendo ainda sensível à liberdade das almas, segundo Panfílio, na escolha de uma vida nova.

IV

Segundo Paul Virilio não há, afinal, “o para além do homem. Nesse plano, o homem é terminal, ele é o fecho das maravilhas de Deus, como o diz Hildegarde de 
Bingen. O homem não é o centro do mundo, ele é o fim do mundo" (2000: 94). Ora no ensaio Invocação ao meu Corpo - escrito em simultâneo com Alegria Breve, romance cujo projeto inicial apresenta uma espécie de osmose destes dois livros de géneros diferentes - o autor reflete, a determinado momento, sobre um outro fim do mundo, pessoal e intransmissível: o da despedida de cada homem da vida, a hora grave em que o corpo humano, onde tudo se passa, retorna à terra da sua condição: “É o fim da vida e do mundo, meu corpo, é a hora de me recolher a ti, à tua divina humildade, é a hora de te agradecer" (Ferreira 1994: 263) ${ }^{16}$. Este fim do mundo é, pois, o da morte de cada homem ou, regressando a Derrida, a morte daquele que amamos anuncia, afinal, "o fim do mundo na totalidade, o fim de todo o mundo possível, e de cada vez o fim do mundo como totalidade única, por conseguinte insubstituível e infinita" (2003: 9).

O fim do mundo de Vergílio Ferreira transmuda-se, assim, em Alegria Breve, Nítido Nulo e Signo Sinal, numa "epopeia de esperança”; só que, no lugar da Igreja e no retorno de Jesus Cristo (parusia), encontramos a Casa do Ser e a celebração da vida, esse "breve nada que é tudo" (Ferreira 1983: 227), como o autor gosta de nos lembrar.

O "último Vergílio" (por nós considerado a partir do romance Para Sempre) diznos porém que, instalada a crise do homem sem fim à vista e perdido o júbilo e a esperança na criação de um mundo novo pelo filho (a partir de Nítido Nulo), o arquiprotagonista procura a serenidade na companhia da mulher amada, real (Clara, no explicit de Até ao Fim) ou imaginária (Para Sempre, Em Nome da Terra, Na tua Face e Cartas a Sandra).

Não é, todavia, uma serenidade como a propugnada por Ângela, a mulher do protagonista de Na tua Face, na sua conferência integrada no ciclo 'No Limiar do Milénio' ("Muita conferência, uma semana delas, ouvi uma ou outra. A superpopulação. 0 costumeiro perigo nuclear. Futuro das ideologias. Nacionalismos e planetização (sic). Cultura e técnica. Crença, crendice, milenarismo. Classicismo e o futuro - era a dela." (Ferreira 1995: 115). A serenidade que Ângela assume ser a do homem futuro é inspirada na ataraxia ${ }^{17}$ de Lucrécio $^{18}$, ou seja, propõe a eliminação das paixões, dos deuses ou de Deus e da angústia do "ser-para-a-morte" no homem:

temos de saber que nada na Natureza é justo ou injusto. Que nada tem significado. Se houvesse justiça nenhum animal matava outro para subsistir. Não morreriam crianças indefesas. Não 
haveria catástrofes na Natureza. 0 homem de amanhã será um homem natural, limpo de todas as ilusões e tranquilo. (idem: 118-119).

Apesar de tranquilo, o arquiprotagonista dos romances do "último Vergílio" não elimina a paixão nem o questionamento da morte. E substitui Deus pela Grande Ordem, como lemos em Para Sempre. E agora que o mundo "já não é capaz de oferecer nada, nem tão-pouco o 'ser-aí com' de outros" (Heidegger 1994: 207), resta ao mesmo arquiprotagonista a sua solarística, isto é, a ciência da palavra que concebe o seu planeta imaginário ou Solaris particular, onde volta a ter a companhia do seu amor maior do que a vida, ou seja, a mulher morta no presente da escrita. E seja o homem uma hipótese improvável, seja uma "paixão inútil" (Sartre) ou absurda, a vida terá sempre, todavia, razão no romance e no pensamento vergilianos:

\footnotetext{
A única matéria que me excita é o próprio homem e tudo o que respeita ao seu destino. Não os seus mecanismos do ser mas do ser vivo no que importa à sua profundeza e mistério e incrível da sua condição. Problemas 'existenciais', digamos, para mais depressa. Que outra coisa o nosso tempo nos permite? (Ferreira 1993b: 74)
}

A solarística vergiliana necessita, todavia, da música para auxiliar a palavra a viajar em direção à sua Solaris ${ }^{19}$ privada. E se essa música é, quase sempre, uma balada de Coimbra, a realidade é que uma música dos Pink Floyd provoca no autor de Para Sempre, como lemos num fragmento do diário, uma imensa saudade do futuro, eliminando, assim, mesmo que temporariamente, a atmosfera pessimista e niilista das suas reflexões sobre a crise da condição humana e a destruição do mundo: "Ouço um disco dos Pink Floyd. É uma melancolia não de quem desistiu e se sentou, mas a de quem se não levantou ainda. Tenho uma saudade imensa do mundo que vai nascer." (Ferreira 1981a: 155).

Outra coisa, em conclusão, não nos diz a palingenesia destas palavras do narrador-protagonista de Até ao Fim: “O universo vai começar, ouço-o no estrondear intenso das águas, como não ser eu aí no começo de mim? E o aroma intenso à vida fertilidade, o mar sabe a voz primordial. (...) A vida inteira dentro de mim." (Ferreira 1988: 227 e 254). 


\section{Bibliografia}

AA.VV. (1984), Novo Testamento, 3. ${ }^{\mathrm{a}}$ ed., trad. e notas de António de Brito Cardoso, índices de A. Vaz da Mota, Braga, Editorial Franciscana.

Barthes, Roland (1982), O Grão da Voz, trad. de Teresa Meneses e Alexandre Melo, Lisboa, Edições 70.

Baudrillard, Jean (1997), A Troca Simbólica e a Morte II, trad. João Gama, Lisboa, Edições 70.

-- (1998), O Paroxista Indiferente, trad. Clara Pimentel, Lisboa, Edições 70.

Camus, Albert (1949), Le Mythe de Sisyphe, 36. ${ }^{\mathrm{a}}$ ed., Paris, Gallimard.

Cunha, Carlos M.F. da (2000), Os Mundos (Im)possíveis de Vergílio Ferreira, Lisboa, Difel.

Derrida, Jacques, De um Tom Apocalíptico Adoptado Há Pouco em Filosofia (1997), Lisboa, Vega.

--, Chaque Fois Unique, La Fin du Monde (2003), Paris, Galilée.

Eiras, Pedro, Constelações 2 - Ensaios Comparatistas (2016), Porto, ILCML e Edições Afrontamento.

Ferreira, Vergílio (1943), o Caminho Fica Longe, Lisboa, Editorial Inquérito.

-- (1979), Signo Sinal, Amadora, Livraria Bertrand.

-- (1981a), UEA - Um Escritor Apresenta-se, ed. Maria da Glória Padrão, Lisboa, INCM.

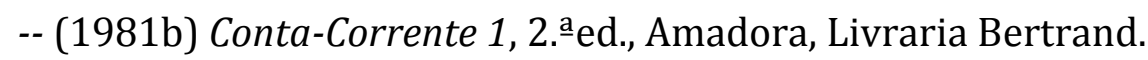

-- (1981c), Conta-Corrente 2, 2. ${ }^{\mathrm{a}}$ ed., Amadora, Livraria Bertrand.

-- (1983), Conta-Corrente 3, Amadora, Livraria Bertrand.

-- (1986a), Conta-Corrente 4, Bertrand Editora.

-- (1986b), Alegria Breve, Lisboa, Amigos do Livro /TV Guia.

-- (1988), Até ao Fim, Lisboa, Círculo de Leitores.

-- (1989), Nítido Nulo, Lisboa, Círculo de Leitores. 
-- (1991), Espaço do Invisível 2, 2. a ed., Venda Nova, Bertrand Editora.

-- (1993a), Espaço do Invisível 3, 2. åed., Venda Nova, Bertrand Editora.

-- (1993b), Conta-Corrente Nova Série II, Venda Nova, Bertrand Editora.

-- (1994), Invocação ao Meu Corpo, 3. a ed., Venda Nova, Bertrand Editora.

-- (1995), Na tua Face, Lisboa, Círculo de Leitores.

-- (2001), Escrever, $2^{\text {a }}$ ed., ed. Helder Godinho, Chiado, Bertrand Editora.

-- (2004), Aparição, 73. ․ ed., Lisboa, Bertrand Editora.

Heidegger, Martin, El Ser y el Tiempo (1994), trad. José Gaos, 8. a reimp., Fondo de Cultura Económica.

-- (1997), Introdução à Metafísica (1997), trad. Mário Matos / Bernhard Sylla, Instituto Piaget.

-- (2000), Serenidade, trad. Maria Madalena Andrade e Olga Santos, Instituto Piaget.

Hölderlin, Poemas (1991), trad. Paulo Quintela, Lisboa, Relógio d'Água.

Júlio, Maria Joaquina Nobre (1996), O Discurso de Vergílio Ferreira como Questionação de Deus, Lisboa, Edições Colibri.

Laso, J.L. Gavilanes (1989), Vergílio Ferreira - Espaço Simbólico e Metafísico, Lisboa, Publicações Dom Quixote.

Lourenço, Eduardo (1994), O Canto do Signo, Lisboa, Editorial Presença.

-- (2001), A Europa Desencantada - Para uma mitologia europeia, Lisboa, Gradiva.

-- (2002), Esplendor do Caos, 4. ㄹ ed., Lisboa, Gradiva.

Lucrécio, Da Natureza das Coisas (2015), trad. Luís Manuel Gaspar Cerqueira, Lisboa, Relógio d'Água.

Mourão, Luís (1990), Conta-Corrente 6 - Ensaio sobre o Diário de Vergílio Ferreira, Câmara Municipal de Sintra.

Pereira, Maria Helena da Rocha, Estudos de História da Cultura Clássica (1990), 2. a ed., Lisboa, Fundação Calouste Gulbenkian. 
Platão, A República (2008), trad. Maria Helena da Rocha Pereira, 11. ${ }^{a}$ ed., Lisboa, Fundação Calouste Gulbenkian.

Sá, Alexandre Franco de (2007), "Heidegger e o fim do mundo", Phainomenon - Revista de Fenomenologia do Centro de Filosofia da Universidade de Lisboa, no 14, primavera de 2007, 241-253.

Virilio, Paul (2000), Cibermundo: A Política do Pior, trad. Francisco Marques, Lisboa, Teorema.

Jorge Costa Lopes é Doutorado em Estudos Literários, Culturais e Interartísticos pela Faculdade de Letras da Universidade do Porto. A sua dissertação, com o apoio de uma bolsa de estudos da Fundação Calouste Gulbenkian, incidiu sobre As Vozes do Silêncio As Marginalia de Vergílio Ferreira nos livros de Fernando Pessoa, Clarice Lispector e Eduardo Lourenço. Em 2014 venceu o Prémio Literário Vergílio Ferreira, na categoria de ensaio, da Câmara Municipal de Gouveia, com o trabalho Sobre o Riso e o Cómico em Vergílio Ferreira, publicado, nesse ano, pela Âncora Editores. Foi o vencedor do Prémio Ensaio/Revelação de 2005 da APE/DGLB com As Polémicas de Vergílio Ferreira, editado em 2010 pela Difel. Organizou e prefaciou a antologia de crónicas e contos de Beldemónio, pseudónimo de Eduardo de Barros Lobo (1857-1893), Jornal de Um Artista, editada em 2008. Tem participado em várias conferências e publicado, em diferentes periódicos, artigos e recensões. 


\section{NOTAS}

$1 \quad<$ http://www.tvi24.iol.pt/acredite-se-quiser/silicon-valley/milionarios-estao-a-gastar-fortunas-commedo-do-fim-do-mundo $>$ (último acesso em 06.03.2017).

$2<$ http://www.jornaleconomico.sapo.pt/noticias/como-milionarios-preparam-fim-do-mundo-119594> (último acesso em 06.03.2017).

${ }^{3}$ Megaprodução que, segundo Pedro Eiras, "pode ser descrita através da (...) má-fé inconsciente" (2016: 238), destacando, mais à frente, que os bilhetes para ingresso nas naves, construídas para a fuga à destruição do planeta terrestre "foram vendidos a preço de ouro" (idem: 239). Os sobreviventes seriam, assim, quase todos milionários, o que não virá a suceder no final do filme, no consuetudinário happy end destas megaproduções hollywoodescas.

${ }^{4}$ Para o projeto de Signo Sinal, Vergílio Ferreira destaca precisamente este poema do heterónimo pessoano: “Apetecia-me uma história como a que conta Pessoa sobre os 'jogadores de xadrez' que imperturbavelmente continuam a sua partida enquanto à volta há, salvo erro, um cerco - é na Pérsia? com mortos, tumultos" (Ferreira 1981b: 196).

${ }^{5}$ Podemos salientar, contudo, que o escritor português não pertence ao círculo dos mais dedicados leitores do autor de Margens da Filosofia, apesar de considerá-lo o "filósofo mais terrível do nosso tempo. 0 termo 'desconstruir' é a chave da sua filosofia e do nosso destino. Derrida destruiu-nos (destruiu?) o último reduto do pensamento. Crise civilizacional" (Ferreira 1981c: 65). De qualquer modo, no verso de um documento preparatório do romance Para Sempre (com a cota E31/432) anota que se inspirou em Derrida para a construção do discurso do professor de filosofia ou linguística de Sandra, na aula a que o narrador-protagonista assiste no capítulo XXIV deste romance: “49 - Derrida (numa aula universitária: a palavra, a a-teologia etc)".

${ }^{6}$ Para o filósofo alemão, o "mundo é sempre um mundo espiritual. 0 animal não tem um mundo nem um circum-ambiente, um circum-mundo (Umwelt). 0 obscurecimento do mundo inclui em si uma despotenciação do espírito, a sua dissolução, o seu definhamento" (Heidegger 1997: 52-53).

${ }^{7}$ Gavilanes Laso destaca, em Alegria Breve, precisamente as "dicotomias de catástrofe e reconstrução, de recordação e visão de futuro, de nada e esperança, etc. Daí o processo cíclico de morte e renovação" (1989: 329).

8 "uma trompete passava em cima, imensa, brilhando palidamente, desdobrando como um lençol, sobre a cidade morta, o seu vasto augúrio - silêncio." (Ferreira 1989: 222). Nítido Nulo é, na realidade, o mais niilista dos romances de Vergílio Ferreira. Não surpreende, por esse motivo, que registe, simbolicamente e em nosso entendimento, a morte da cidade do homem que Alberto Soares pretendia construir. 0 mesmo em relação à morte da esperança na vinda redentora do filho de Alegria Breve que se irá revelar um malogro em Nítido Nulo. 
${ }^{9} \mathrm{Na}$ visão alucinada de Jorge Andrade, o mar surge repleto de milhões de cadáveres em mais um quadro apocalíptico vergiliano: "Na areia pálida, as sombras, a praia está deserta, uma frialdade coalhada, os meus pensamentos descem à escuridão dos mortos. Vejo-os, aliás, flutuar agora, cadáveres nus e de bruços, crescem aos montões multiplicam-se na extensão fria das águas. São milhares, milhões de cadáveres, acostados uns aos outros, o dorso esbranquiçado mergulhando, emergindo, balouçando devagar a todo o horizonte marinho. Arrastados decerto por todos os rios do mundo como troncos de árvores de uma floresta, flutuam plácidos, de bruços, as águas gordas da sua massa, flutuam lentos à luz pálida da tarde" (Ferreira 1989: 254).

10 Recordemos os "montes de carne podre / que fedem..." do poema, atrás citado, de Rui Antunes em $O$ Caminho Fica Longe.

11 "Ora o homem fundamental é o que diz 'não', como é dos livros - nada mais nos coube, que é que havia de fazer? Mas dizer 'não' é prodigioso, o gado humano não sabe. Dizer 'não' é abrir um espaço para o homem se pôr de pé" (Ferreira 1989: 117).

12 Com a cota E31/290. 0 documento manuscrito diz o seguinte: "Alegria Breve / Tema geral. A crise de hoje em: a) política; b) arte; c) amor; d) religião e: a pequena esperança para o futuro (a alegria breve)".

13 'Quanto a um próximo romance meu [Alegria Breve], o seu 'tema', ou o que nele me é obsessão, é a crise imensa do nosso tempo (talvez mesmo crise de 'liquidação') e a invencível certeza de que, apesar de tudo isso, o homem continuará..." (Ferreira 1981a: 357), salientou Vergílio Ferreira numa entrevista recolhida por Maria da Glória Padrão.

${ }^{14}$ A edição que seguimos é a que se encontra na Biblioteca Municipal Vergílio Ferreira de Gouveia e integrada no espólio bibliográfico doado pelos herdeiros do autor de Alegria Breve. O leitor Vergílio Ferreira não sublinhou, porém, e contrariamente a inúmeros outros excertos deste livro, o por nós citado.

$15 \mathrm{Vd}$. o nosso ensaio "Anjo guerreiro, arcanjo vencido ou Heróstrato moderno? - 0 jovem em Vergílio Ferreira" in Cadernos de Literatura Comparada n. 29 (2013), Margens \& Periferias. Perspetivas de Inclusão: 165-188; < http://ilc-cadernos.com/index.php/cadernos/article/view/331/310> (último acesso em 06.03.2017).

16 Porque, como assinala a personagem Amadeu em Alegria Breve, agora "temos de nos bastar a nós próprios. Ora bem: o homem começa e acaba no seu corpo" (Ferreira 1986: 118). Ou, de acordo com esta entrada do diário: "Mas um homem que morre é o último homem que morre, como aquele que nasce é o primeiro. Todo o destino do universo se resolve assim em cada vida humana. Quando a espécie findar, o último homem de então será igual ao que morre hoje, quando a espécie se continua. E todavia, não o sabemos" (Ferreira 1981b: 393).

${ }^{17}$ Maria Helena da Rocha Pereira observa que a moral de Lucrécio é "quietista, utilitarista e individualista" (1990: 102). Deste modo, a sua ataraxia ou "ausência de perturbação" (ibidem) é diferente da dos estoicos, 
que designava "um estado de espírito que se alcançava por via oposta - o domínio de si mesmo e a contenção." (ibidem). Ora é esta a ataraxia, praticada por Horácio, do arquiprotagonista do "último Vergílio", e não a de Ângela de Na tua Face, personagem em que é notória e, por vezes, quase excessiva, a "ausência de perturbação" defendida pelo seu filósofo.

${ }^{18}$ A destruição da Terra também foi objeto de reflexão do filósofo latino, como verificamos nestes versos: "E não escapa ao meu espírito quão grande e surpreendente novidade / é para a mente a ideia de que háde haver uma destruição do céu e da terra / nem quão difícil é para mim convencer-te disso com palavras / (...) tu mesmo verás tudo ser abalado em segundos, / com o surgimento de fortes tremores de terra. / Tal coisa afaste para longe de nós a Fortuna que tudo governa, / e que seja antes a razão e não a própria coisa a persuadir-nos / de que o universo pode desabar, vencido, com um horríssono fragor." (Lucrécio 2015: V, 96-110).

19 Vergílio Ferreira substitui, no romance Para Sempre, o topónimo Coimbra pelo imaginário Solária ou Soeira. Parece-nos, assim, evidente a similitude entre o nome do planeta do livro de Stanisław Lem, bem como dos filmes de Andrei Tarkovski (1972), que Vergílio Ferreira viu, mas não apreciou por aí além, e de Steven Soderbergh (2002), e aquele da cidade estudantil do romance do escritor português. 



\title{
0 mundo já está a acabar?
}

\section{E.M. Forster discute Whatsapp, Skype e Questia, ou uma leitura de "The Machine stops" (1909)}

\author{
Sofia Araújo \\ Universidade do Porto - CETAPS / CITCEM / ILC-ML / IF
}

Resumo: A proximidade de alguma da imagística de "The Machine stops" a realidades contemporâneas ligadas primordialmente às utilizações da Internet gera a aplicação do célebre critério: relevância. A comunicação através de ecrãs das personagens descreve com exactidão a era de Skype e Whatsapp. Que mundo descreveu E.M. Forster em 1909 e que mundo encontramos nele em 2017? E se o dele acaba em apocalipse, quer dizer que já estamos a caminho?

Palavras-chave: E.M. Forster, distopia, utopia, Apocalipse, ficção científica, Internet

Abstract: The link between some of the images in "The Machine stops" and current Internet-based living circumstances earns E.M. Forster's short-story the coveted title of 'relevant'. On-screen communication between characters describes to a tee the workings of Skype ou Whatsapp. What was the world that E.M. Forster created in 1909 and what world do we read in it in 2017? And if his resulted in apocalypse, are we to assume we are well on our way there?

Keywords: E.M. Forster, dystopia, utopia, apocalypse, sci-fi, Internet 
Long books, when read, are usually overpraised,

because the reader wishes to convince others and

himself that he has not wasted his time.

E.M. Forster, Aspects of the Novel

Se reconhecermos a análise literária como sendo domínio da crítica - como tal, subjectivo e criativo $^{1}$-, teremos igualmente de reconhecer as categorias que nela aplicamos como algo de, por essência, não estanque e de valorativo (por oposição a descritivo). Quando essas categorias são particularmente amplas ganham contornos mais carregados que reflectem ponderações, quase sempre colectivizadas (ou, pelo menos, sempre particularmente colectivizáveis), de gosto e de mérito. Poucas distinções são de tal forma marcadas como aquela entre 'ficção científica' e 'literatura a sério', com a 'ficção científica' a ser resgatada enquanto artefacto político-cultural ou histórico, mas geralmente considerada inferior (enquanto objecto estético e muitas vezes mesmo filosófico). Alguns autores - como Kurt Vonnegut e Ray Bradbury - conseguem (quase) escapar a este maniqueísmo analítico. Alguns outros - como Jules Verne, H.G. Wells ou Arthur C. Clarke - são geralmente tomados por reféns de colectâneas de literatura juvenil ou de verão. Outros ainda - como Ballard e Isaac Asimov - aguardam ainda julgamento. Assim, quando um autor "a sério"2 faz ficção científica, esta é geralmente tomada como trabalho menor, de cariz lúdico ou experimental, mas sempre quase acidental. Se o acaso fizer com que esse texto seja efectivamente menor no que ao volume diz respeito, a caracterização fica reforçada. É o que acontece com o conto/novela (not-so-short story) "The Machine stops" publicado em 1909 por E.M. Forster (1879-1970).

Um ano depois de A Room with a View (1908) e um ano antes de Howards End (1910), o autor de A Passage to India (1924) assina uma visão de um futuro distópico com pretensa esperança utópica final. A história decorre algures num futuro que nos parece peculiarmente próximo da actualidade tecnológica ocidental. Daí decorre um renovado interesse por este texto, agora de leitura livre, que, por irónico paradoxo, se multiplica em cópias electrónicas, partilhas directas e indirectas e comentários 
surpresos e quase sempre encantados, desde os mais imediatistas às mais detidas reflexões. Em 2016, Juliet Forster dirige para o palco do York Theatre Royal uma adaptação assinada por Neil Duffield. Dramaturgo e encenadora demonstram bem esta reencontrada pertinência: “It's a warning for now for what we might be getting ourselves into", diz Neil Duffield, e "[Y]ear on year, it's gained more and more relevance [...] Forster had such insight into human nature and the way we would adapt and lose parts of ourselves through technology", acrescenta Juliet Forster (apud Long 2016). De facto, a proximidade de alguma da imagística de "The Machine stops" a realidades contemporâneas ligadas primordialmente às utilizações da Internet gera a aplicação do célebre critério: relevância. A comunicação entre as personagens através de ecrãs descreve com exactidão a era de Skype e Whatsapp e evoca as suas consequências afectivas e efectivas, entre comunicação constante e solidão individual, sexting e síndrome de abstinência electrónica:

\footnotetext{
'I want you to come and see me.'

Vashti watched his face in the blue plate.

'But I can see you!' she exclaimed. 'What more do you want?'

'I want to see you not through the Machine,' said Kuno. 'I want to speak to you not through the wearisome Machine.'

'Oh, hush!' said his mother, vaguely shocked. 'You mustn't say anything against the Machine.'

'Why not?'

'One mustn't.

'You talk as if a god had made the Machine,' cried the other. 'I believe that you pray to it when you are unhappy. Men made it, do not forget that. Great men, but men. The Machine is much, but it is not everything.' (Forster 2011: 3)
}

Se a segunda metade do século XIX foi marcada pela "representação redentora das técnicas de comunicação e de transporte [que se funde] com os grandes relatos do progresso e da democracia", como refere Armand Mattelart ${ }^{3}$ (2000: 150), a primeira metade do século XXI vive com um deleite muito mais temeroso a vertigem de avanços tecnológicos na comunicação. É neste campo específico, e não no receio tecnológico, que o enfoque de "The Machine stops" se nos revela tão pertinente. A associação de avanços científicos a um potencial de auto-destruição não é de todo nova, e a ideia de 
possibilidade de destruição integral, de apocalipse, de fim do mundo pela ciência/tecnologia é anterior até à sua própria factibilidade: a mero título de exemplo, no século XVIII Jonathan Swift confrontou Gulliver com a invenção pelos cientistas de Laputa de uma arma avançadíssima cuja utilização, contudo, implicaria a destruição da ilha - Michael Foot afirmará depois que o misantropo Swift antecipara a era nuclear ${ }^{4}$. Em 1922 Lewis Mumford, em The Story of Utopias está já plenamente ciente da possibilidade como enfoque da reflexão ética no texto utópico e, depreendo, na própria ficção científica:

A community which cultivates chemical science to the point at which it is able to wipe out a whole city by a few explosions of poisonous gas is in a pretty treacherous situation. If the science that it possesses has not helped to found a eutopia, it has at any rate provided the foundations for a kakotopia, or bad place: in short, for a hell. Indeed scientific knowledge has not merely heightened the possibilities of life in the modern world: it has lowered the depths. When science is not touched by a sense of values it works - as it fairly consistently has worked during the past century - towards a complete dehumanization of the social order. (Mumford 1922: 276)

Em 1934 irá mais longe e, em Technics and Civilization, avançará uma ideia precisamente irmanada com a criação de Forster: a divisão de tecnologia em politecnia e monotecnia, sendo esta última (Mumford pensava no carro) de tal forma avassaladora e absorvente que extirpa alternativas e subjuga o Homem. Ora, o que torna o conto de Forster tão curioso é a ênfase que coloca não em questões bélicas ou locomotivas, mas naquelas que são hoje as questões centrais da relação Humano-Tecnologia: a comunicação, a dependência e, derradeiramente, a fronteira entre Homem, Máquina e Deus.

Em “The Machine stops" mãe e filho, convertida e revoltoso, apresentam-nos um mundo em que o ser humano vê todas as suas necessidades (e ensejos, mais do que desejos) serem supridos pela intervenção de uma omnipresente Máquina, maiusculizada como uma espécie de Deus. 0 seu funcionamento assegura a Vida; a sua ruptura equivale a um final da existência humana. Não é inaudita em E.M. Forster, na abertura do século XX, a emancipação de um pensamento religioso - David Lodge recorda: "Forster described himself as 'a child of unbelief,' meaning that, to his generation of intellectuals, atheism and agnosticism came very easily, with none of the traumas suffered by their 
Victorian predecessors over the loss of Christian faith" (2003: 143). Simultaneamente, esta humanidade satisfeita torna-se usufrutuária inerte, um ser mantido em celas/palácios individuais subterrâneos pelo sistema que criou. A existência humana tornada autónoma da sua autenticação pelo trabalho, sendo uma questão tão forte na actualidade, com todas as discussões em torno do rendimento básico universal e as leis laborais no uso de robots, é uma questão igualmente actual na entrada do século XX. Peter Firchow, investigador dos estudos utópicos, refere a propósito do que considera ser o conto "anti-utópico" de Forster que "o fim desejado" se converte num "hedonismo animalesco e, pior, aborrecimento" (2007: 6-7) ${ }^{5}$.

Uma apatia quase bovina caracteriza estes habitantes que pecam na ausência de curiosidade ("By her side, on the little reading-desk, was a survival from the ages of litter - one book. This was the Book of the Machine. In it were instructions against every possible contingency. If she was hot or cold or dyspeptic or at a loss for a word, she went to the book, and it told her which button to press. The Central Committee published it. In accordance with a growing habit, it was richly bound." (Forster 2011: 8-9)) no reconhecimento de conceitos (" 'The Machine stops.' 'What do you say?' / 'The Machine is stopping, I know it, I know the signs.' She burst into a peal of laughter. He heard her and was angry, and they spoke no more. 'Can you imagine anything more absurd?' she cried to a friend. 'A man who was my son believes that the Machine is stopping. It would be impious if it was not mad.' 'The Machine is stopping?' her friend replied. 'What does that mean? The phrase conveys nothing to me.' 'Nor to me.'” (45)), se imobilizam perante o estabelecimento de opiniões ("'I want to visit the surface of the earth.' She was shocked again. 'Mother, you must come, if only to explain to me what is the harm of visiting the surface of the earth.' 'No harm,' she replied, controlling herself. 'But no advantage.'” (5)) e se aninham como crianças no refúgio de um ser mitológico que sabem sua criação ("Vashti was afraid. 'O Machine! O Machine! She murmured, and caressed her Book, and was comforted." (15)).

E.M. Forster, tantas vezes complexo e até enigmático, mantém aqui a fluidez que Jorge de Sena lhe atribui 6 , mas usa um tom argumentativo circular, explícito, quase didáctico neste texto mais curto e tão sui generis na sua produção. Poderemos então dizer que há um desejo programático, um ângulo didáctico neste texto distópico em que 
a vontade de conhecer uma Humanidade (ainda/já) sem Máquina e a ruptura dessa Máquina geram o apocalipse da nova civilização? Veja-se o final quase homilético do texto:

'I am dying - but we touch, we talk, not through the Machine.'

He kissed her.

'We have come back to our own. We die, but we have recaptured life, as it was in Wessex, when Aelfried overthrew the Danes. We know what they know outside, they who dwelt in the cloud that is the colour of a pearl.'

'But, Kuno, is it true? Are there still men on the surface of the earth? Is this - this tunnel, this poisoned darkness - really not the end?'

He replied:

'I have seen them, spoken to them, loved them. They are hiding in the midst and the ferns until our civilization stops. To-day they are the Homeless - to-morrow -'

'Oh, to-morrow - some fool will start the Machine again, to-morrow.'

'Never,' said Kuno, 'never. Humanity has learnt its lesson.'

As he spoke the whole city was broken like a honey-comb. An air-ship has sailed in through the vomitory into a ruined wharf. It crashed downwards, exploding as it went, rending gallery after gallery with its wings of steel. For a moment they saw the nations of the dead, and, before they joined them, scraps of the untainted sky.' (Forster 2011: 55-6)

Autores primordialmente optimistas como Giampero Bof tendem a associar o discurso utópico a uma fé escatológica e um final civilizacional, mas o papel da distopia prova uma vez mais ser o de antecipar os fins desejados e desnudar-lhes a real natureza. Forter continua Forster. E o futuro, esse, continua, como sempre, matéria do 'agora'. 


\section{Bibliografia}

Ballester, Gonzalo Torrente (1999), Sobre Literatura e a Arte do Romance, Algés, Difel.

Bof, Giampero (1993), “Escatologia e Utopia”, in Arrigo Colombo (org.) (1993), Utopia e Distopia, Bari, Edizioni Dedalo: 261-78.

Firchow, Peter Edgerly (2007), Modern Utopian Fictions from H. G. Wells to Iris Murdoch, Washington: The Catholic University of America Press.

Foot, Michael (1967), "Introduction", in Jonathan Swift (1967), Gulliver's Travels, Baltimore, Penguin Books [1726].

Forster, E.M. (2011), The Machine Stops, Londres, Penguin.

Lodge, David (2003), Consciousness and the Novel, Londres, Penguin Books.

Long, Chris (2016), “'The Machine stops': did E. M. Forster predict the internet age”, in BBC News, 18 de Maio de 2016, <www.bbc.com/news/entertainment-arts-36289890>, (último acesso em 14 de janeiro de 2017).

Mattelart, Armand (2000), História da Utopia Planetária. Da cidade profética à sociedade global, Lisboa, Editorial Bizâncio.

Mumford, Lewis (1922), The Story of Utopias, Nova Iorque, The Viking Press.

Sena, Jorge de (1989), A Literatura Inglesa, Lisboa, Edições Cotovia. 
Sofia de Melo Araújo é Doutorada, como bolseira da FCT, em Estudos AngloAmericanos, sob orientação das Professoras Doutoras Maria de Fátima Marinho e Fátima Vieira, pós-graduada em Literatura Portuguesa e Brasileira e licenciada em LLM - Variante Estudos Portugueses e Ingleses (Ramo Pedagógico) pela F.L.U.P. Docente da Escola Superior de Educação - Instituto Politécnico do Porto. Criadora e docente da cadeira Escritores Portuenses: uma Abordagem Ética da Literatura no âmbito do PEUS-Universidade do Porto. Docente de Inglês Académico (níveis avançados) da Universidade do Porto desde 2013. De 2006 a 2008 monitora de Literatura Universal na Universidade Católica do Porto, sob coordenação do Professor Doutor Arnaldo Saraiva. Colaboradora dos grupos de investigação CITCEM, CETAPS, Instituto de Filosofia (IF) e Instituto de Literatura Comparada - Margarida Losa.

\section{NOTAS}

\footnotetext{
${ }^{1}$ Concordo com Gonzalo Torrente Ballester: “O texto é sempre como uma partitura que cada um toca a seu modo: só pode ser entendido a partir da experiência de cada um, e a experiência é própria dos indivíduos e não é intercambiável, nem há experiências melhores do que outras" (1999: 213-4).

2 Esta é uma leitura geralmente feita de Forster, apesar da validade daquilo que refere David Lodge: "E.M. Forster has always occupied a problematic position in the literary history of the twentieth century. He is generally recognized as a major modern novelist, with a place in the same pantheon as Henry James, Joseph Conrad, James Joyce, Virginia Woolf, and D. H. Lawrence. But even the admiring Trilling observed, shrewdly, that 'he is sometimes irritating in his refusal to be great"' (2003: 153-4).

${ }^{3}$ Mattelart reconhece de imediato a existência também de atenção a potencial negativo. Veja-se a citação em contexto mais amplo: "A representação redentora das técnicas de comunicação e de transporte triunfa na segunda metade do século XIX, e funde-se com os grandes relatos do progresso e da democracia. A normalização das redes internacionais do telégrafo (mas também dos correios) conjuga-se com as figuras da concórdia universal. Antes mesmo de os cientistas terem conseguido dominar o 'mais pesado do que o ar', as máquinas voadoras espevitavam o imaginário da libertação humana. A imagem que, a partir das duas últimas décadas do século XIX e até às vésperas da Grande Guerra, os romances de ficção científica projectam do futuro do mundo oscila entre a promessa duma Cidade mundial e o apocalipse dum globo aniquilado pela guerra total e planetária. As controvérsias sobre os efeitos da generalização dum
} 
racionalismo tecnicista guiado exclusivamente pela busca do lucro dividem os meios socialistas, que se interrogam sobre as possibilidades de dominar as aplicações sociais das inovações para fins de emancipação. A cobertura do território pelos fios e cabos eléctricos suscita uma nova esperança de democracia descentralizada. A partir do momento em que é inventado, o cinematógrafo assume o papel de 'agente de ligação da humanidade'” (2000: 150).

${ }^{4} \mathrm{Cf}$. Foot: "If the story of the king and his ingenious scientists, who invented an all-conquering contraption which could only be used at the price of blasting all Laputa to kingdom come, is not a prophecy of the Hbomb, I will eat my academic hat and surrender my literary critic's cloak altogether" (1967: 29).

${ }^{5} \mathrm{Cf}$ texto integral original: "One of the great fears of the anti-utopians with respect to technological progress is that it will ultimately deprive all but a tiny minority of people - or perhaps even everyone - of anything 'useful' to do; it will, in other words, substitute itself for actual lived life. This is a fear, it should be noted, that precedes by many decades the current denigration of 'virtual' or computer-generated reality. It is, for example, clearly expressed in E. M. Forster's anti-utopian short story 'The Machine Stops'. Humanity is now faced with a problem for which humanity is utterly unprepared because hitherto it had never presented itself as a problem. Previously it had, in fact, been a desirable end. This new and unanticipated problem is what to do with a life in which work is no longer required - is, in fact, no longer even possible. In a world where leisure is compulsory, utopian existence suddenly seems horrifying precisely because it is 'utopian,' because it is so easy and comfortable and, paradoxically, so unproblematic. Utopia, it turns out, delivers for most of its inhabitants not intellectual and emotional challenges, but an animalistic hedonism and, what is perhaps even worse, boredom. Aldous Huxley's Brave New World is the classic example of a future society in which technology has - magically and ironically - provided humanity with all it had thought it desired." (Firchow 2007: 6-7).

${ }^{6}$ Cf. "Os argumentos das suas narrativas são muitas vezes fluídos ou arbitrários, para que - e é o que lhe importa - as personagens se vejam em situações que, despindo-as da personalidade convencional que usavam, lhes não permitem recobrir-se da convencionalidade romanesca que a verosimilhança recria" (Sena 1989: 350). 



\section{Libretos}

XX ILCML

FCT Fundação para a Ciência e a Tecnologia MINISTÉRIO DA CIÊNCIA, TECNOLOGIA E ENSINO SUPERIOR

UID/ELT/00500/2013
COMPETE 2020 PORrucat 2020

POCI-01-0145-FEDER-007339 